\title{
Translating the Untranslatable: Walter Benjamin and Homi Bhabha
}

Vladimir Biti

Institute of Slavic Studies, University of Vienna, Spitalgasse 2 / Hof 3, 1080 Vienna, Austria vladimir.biti@univie.ac.at

Since Homi Bhabha introduced the notion of 'cultural translation' in the penultimate chapter of his Location of Culture, translation no longer implies the overcoming of existing differences between cultures. In his peculiar interpretation, it becomes a process that initiates cultural differences in the same way as life, for instance, incessantly diversifies its creatures. As these differences follow from translation, rather than precede it, cultures are conceived as hybrid and in-between rather than pure and autonomous entities. It is this characteristics of cultures that, in Bhabha's understanding, renders them untranslatable. A culture cannot assimilate into another culture without maintaining its internal difference and it cannot liberate itself from another culture without having embodied this culture's trace. In the final analysis, his idea of "cultural translation desacralizes the ... assumptions of cultural supremacy" by undoing the asymmetry between languages that for long centuries accompanied the Western practice of translation. The thesis that I want to propose is that, in this context, Bhabha's engagement of the notion of untranslatability, introduced by Walter Benjamin in his 1923 essay "The Task of the Translator", acquires a special significance. It establishes a clandestine 'elective affinity' between the two thinkers who, doomed to cope with the traumatic constellations of their respectively post-imperial and postcolonial age, attempt to disengage these ages' political asymmetries.

Keywords: translation theory / interculturality / cultural differences / intranslatability / post-imperialism / post-colonialism / Benjamin, Walter / Bhabha, Homi

\section{The rise of the indistinct: Two affiliated post-ages}

Since Homi Bhabha introduced the notion of 'cultural translation' in the penultimate chapter of his Location of Culture (303-338), translation no longer implies the overcoming of existing differences between cultures. In his peculiar interpretation, it becomes a process that initiates cultural differences in the same way as life, for instance, incessantly diversifies its creatures. ${ }^{1}$ As these differences follow from translation,

${ }^{1}$ Vladimir Biti is currently Distinguished Chair Visiting Professor at Guangdong University of Foreign Studies and Zhejiang University. 
rather than precede it, cultures are conceived as hybrid and in-between rather than pure and autonomous entities. Since the translation as their generator eludes identification, the differences between them are neither absolute nor reducible to a common identity. Exempting the translation from the bifurcations that it continuously generates, Bhabha renders it untranslatable. To underline its promotion to the condition of the im/possibility of all its constituent parts, he replaces languages as its objects with cultures as its reproducers. This argumentative move automatically eliminates the key dilemma of traditional translation theory: either the translator assimilates his or her language to that of the source text or makes the target text function as part of an altogether different linguistic setting. By insisting on the resistance that one culture offers both to its assimilation into the other culture and to its complete separation from it, Bhabha disengages binary logic. A culture cannot assimilate into another culture without maintaining its internal difference and it cannot liberate itself from another culture without having embodied this culture's trace. This is why no culture brings the process of translation to a successful closure. Instead, this process cuts through distinct cultural identities by making them essentially indistinct. As a result, Bhabha implies that the post-colonial world turns the colonial world's hierarchy upside down, establishing indistinction as its norm instead of distinction. In its global multinational network, hybridity, liminality, and in-betweenness rule the day.

In addition, such a globalization of translation undermines the 'selfevident' opposition that has dominated reflection on this notion over many centuries of colonialism. By extending the translation from the linguistic to the cultural domain, Bhabha seems to be reminding us that, from the outset, the practice of translation accompanied European colonialism with its habitual asymmetries between the rich and the poor or the civilized and the barbarous cultures. By undoing these asymmetries as the instruments of domination, he is in fact interrogating the colonial power relationship. In his own words, his idea of "cultural translation desacralizes the ... assumptions of cultural supremacy" (228). The thesis that I want to propose is that, in this context, his engagement of the notion of untranslatability, introduced by Walter Benjamin in his 1923 essay "The Task of the Translator", acquires a special significance. It establishes a clandestine 'elective affinity' between the two thinkers who, doomed to cope with the traumatic constellations of their respectively post-imperial and postcolonial age, take recourse to the weak messianic strategy that systematically postpones its redemption. The latter has a long tradition in European modernity strictu senso, which 
dates back to early German Romanticists who were equally "stranded in their present," longing to reconnect with their castrated past via its scattered ruins (Fritzsche 55-131). ${ }^{2}$ The redrawing of international borders in the aftermath of the German Empire's breakup induced an irreparable loss of security. The Romanticist identification of the foreclosed possibilities of the past and their restoration of its neglected itineraries were defensive responses to the disappointments induced by the French Revolutionaries' investment in historical progress. Their triumphant history penetrated deeply into the lives of its many participants with devastating effects.

In the similar atmosphere of an unchained history after the crumbling of an empire, what drives Bhabha to evoke Benjamin's notion of untranslatability? We should remind ourselves that, in the post-imperial constellation, this notion disengaged the ruling conception of language, which reflected European imperial asymmetries in the same way that the prevailing conception of translation, at the post-colonial time into which Bhabha intervenes, reflected European colonial asymmetries. Thus, what might have attracted Bhabha in Benjamin's notion are the emancipating political implications in its background. The untranslatable is the element that offers resistance to the translational mechanisms of victorious history, which promotes Bhabha's turn to Benjamin as an example of how his "insurgent intersubjectivity" (Bhabha 230) comes into being. However, the notion of the untranslatable only appears at one spot in Benjamin's essay and is difficult to understand without considering his whole argument as being scattered across several essays. The respective point reads that "translations prove to be untranslatable" due to the "all too great fleetingness with which meaning attaches to them" ("The Task" 82, trans. modified, allzu großer Flüchtigkeit, mit welcher der Sinn an ihnen haftet, "Die Aufgabe" 61). It deserves attention that the German term Flüchtigkeit is associated with the notion of the Flüchtling (escapee or migrant), which significantly takes center stage in Bhabha's essay mentioned above. Benjamin seems to be suggesting that meaning remains a subversive migrant in any language that tries to domesticate it. Placed amidst its national identity, it introduces transnational displacement into its place, or indistinction into its distinction. In other words, before an act of its inter-lingual translation, any language's meaning undergoes an intra-lingual escape, which makes its identity indistinct. Its internal fleetingness offers resistance

${ }^{2}$ In his more extensive genealogy, Agamben traces weak messianism back to $\mathrm{St}$ Paul, see The Time That Remains 88-112. 
to all acts of its translation into another linguistic identity, rendering it restrictive.

Insisting on such internal "untranslatability" of national languages, Benjamin might have established a spontaneous association with the untranslatability of the dispersed Jews as the perennial migrants of European cultures into every established national identity. For centuries they were caught "in a constant state of flux" ("The Task" 78), which destined them to "homelessness" "throughout the world," as Gustav Mahler remarked in the sinister atmosphere of their renewed dispossession (Beller 207) that, nota bene, also gave birth to Benjamin's essay. At the time, however, the same inherited homelessness endangered the awakened national languages that, in the compartmentalized post-imperial Europe, were fiercely vying for their own political identity. For long centuries, they were likewise deprived of it. Benjamin's notion of untranslatability opposes the idea of their national self-determination as the antidote to this homelessness in the same way that it opposes the rising Zionist idea of Jewish national self-determination. Instead, by transforming their painful lack of distinct identity into a rare privilege, he turns their homelessness into an appointment for a revolutionary mission. Benjamin's contemporary Karl Kraus, before he turned Zionist, equally trusted that the Jews were "fated to dissolve entirely into their surrounding cultures, and nevertheless still to remain a ferment in them" (Kraus 23). ${ }^{3}$ Like him, Benjamin was convinced that the inflicted internal exteriority to any host culture forced the Jews "to come to terms with things in a way others, generally, were not [forced]. There was thus, in a sense, a special role for Jews, one might say a secular version of the chosen people" (Beller 217). Like the migrant meaning at the heart of national languages, they were invited to permanently revivify their hosts' identities by introducing indistinction into their distinction.

Significantly, speaking of cultural translation, Bhabha renders the impact of Indian migrant families on the British post-colonial surrounding in similar terms of a persistent renewal. Their cultural untranslatability permeates the cultural milieu of their hosts with "hybrid sites of meaning" (234), which culminates in "an empowering condition of hybridity; an emergence that turns 'return' into re-inscription or redescription; an iteration that is not belated, but ironic and insurgent" (324). In Bhabha's view, this is "how newness enters the world". In both

${ }^{3}$ Here, and in what follows, all translations from German are mine unless otherwise indicated. 
typically remedial arguments, the humiliating condition of migrants, bereft of distinct identity properties, translates into a life-affirming force. To be sure, neither Benjamin nor Bhabha invented this compensatory argument. Already early German Romanticists, embittered by the dissolution of the German Empire through Napoleon's victorious rise to power, had turned the long-term dispossession of German identity through the supremacy of French culture into a source of national pride. In their significant thesis on the German identity in permanent making, its lack of distinction was transformed into an advantage (Biti 57-68). This consoling self-glorifying maneuver of turning the lack of an autochthonous national tradition into an advantage in comparison to France or England was almost commonplace in the culturally inferior Germany around 1800 (Herder 551; Schlegel 26; Wiedemann $545 f f . ; ~ K o c h ~ 234 ;$ Albrecht 308).

\section{Benjamin's notion of the untranslatable and its implications}

With the inborn instinct of all deprived agencies, which tend to interlock in order to strengthen their resistance, Benjamin's and Bhabha's arguments establish "affiliative solidarity" (Bhabha 230) with the Romanticist remedial logics. However, in counter-distinction to Bhabha, who in post-colonial circumstances is preoccupied with the migration of people, Benjamin focuses on the translation of languages in post-imperial circumstances. In order to understand his idea of untranslatability in the whole range of its implications, we must first take a closer look at the distinction he draws, within a given language, between its intended object (das Gemeinte) or particular referent and its mode of intention (die Art des Meinens) or structure of reference. $\mathrm{He}$ engages it throughout his argument, consistently applying it to both artworks and languages. In both, the structure of reference, genuine to their respective memory archives, outdoes the referent, which an artist or speaker establishes by his or her particular communicative intention. Benjamin already states in the first paragraph of his essay, in which he addresses the nature of artworks, that, despite the artist's intentions, "no poem is intended for the reader, no picture for the beholder, no symphony for the listener" ("The Task" 75). The structure of reference genuine to these artworks - or what semiotics has thereupon termed signification - goes far beyond the referent or denotation intended by their respective producers. Applying this distinction between signification and denotation to languages, Benjamin claims that they converge 
in the referents of their particular words but diverge in their structures of reference, inasmuch as these by far exceed these referents. The languages cannot control their structures of reference because, firstly, these are "in a constant state of flux" and, secondly, continuously supplement each other (78). Benjamin's elusive signification thus anticipates LéviStrauss's concept of the floating signifier (Lévi-Strauss 63-64), which was recently designated by Giorgio Agamben to have been the "guiding concept in the human sciences of the twentieth century" (State of Exception 37).

What makes artworks and languages untranslatable is precisely their elusive signification, even if their transmitters ceaselessly translate it into particular denotations. Nonetheless, each materialized meaning excludes from its horizon a vast surplus of non-materialized ones that envelop this meaning. In Benjamin's view, this envelopment of unemployed meaning possibilities determines the reception of the given meaning behind the back of the intention that established it. As the artworks and languages cannot take into possession that which they translate but remain exposed to its untranslatability, their meaning involuntarily reaffirms this untranslatability by itself becoming "fleeting." However, the level of this fleetingness depends on their ability to activate their originals' "untranslatable element" or unemployed meaning possibilities. As the resolute advocate of the suppressed life options, Benjamin entrusts the translator with the task of such mobilization. If he or she succeeds in fulfilling this task of translating the zone of indistinction beyond the original's distinct meaning horizon, the latter experiences its rebirth or return to life.

Following this line of thinking, Benjamin warns that the translational activity retains its "possibly foremost significance" if it is not focused "exclusively on man" but rescues from oblivion that which men "proved unable to translate" (76). That is to say, the untranslatable that obliges the translator exceeds the structures of reference of human languages. That which they cannot translate is bare life (bloßes Leben; "Zur Kritik der Gewalt" 202-203) as a dense network of relations, which operates beyond these languages. This network comes to expression in all of its manifestations in the form of their escaping origin that undermines their distinction and sovereignty. ${ }^{4}$ Recently, Agamben resumed it in his political philosophy, rendering bare life

${ }^{4}$ This is why Benjamin, for example, in The Origin of German Tragic Drama, interprets the German word Ur-sprung (which in everyday usage means "origin") etymologically as a "primordial leap" (out-of-control) (Der Ursprung 226). 
(la nuda vita) (Homo Sacer 4, 9, 10, 18, 27-28) as the underground ferment of the revolutionary change of given political formations. Its "zones of indistinction" operate as the reservoirs of "pure potentiality" that precedes and blurs human political divisions. Accordingly, within the constellation of European modernity, "bare life has the peculiar privilege of being that whose exclusion founds the common being of men" (10; trans. modified, la città degli uomini). However, it structures the human world from an 'outside' that adheres to it only "through a disjunction and an anachronism" (Nudities 11).

Anchored as they are in bare life, modern political formations demonstrate "the topological structure of the state of exception": "being outside, and yet belonging" to the juridical state (State of Exception 35). Concerning this structure, Agamben unhesitatingly draws an analogy with the above-addressed excess of signification over denotation: "Just as between language and word, so between the juridical norm and its application there is no internal nexus that allows one to be derived immediately from the other" (40). Both passages entail "a 'trial' that always involves a plurality of subjects" (39-40), remaining controversial and conflict-ridden. This is how Benjamin's notion of the untranslatable establishes an unmistakable link with the political state of exception. Although residing outside its translations, the untranslatable haunts them by inducing their destabilizing, floating, and meandering.

\section{Miming as the medium of indistinction}

This consistently inappropriate translation of the untranslatable - or miming - as it cannot but eternally postpone its verification, marks the very core of Benjamin's weak messianism. The divine world, because it is forever lost, occupies a constitutively ecstatic position toward the human world. It only belongs to this world through its exemption from it in the same way that the sovereign, in the state of exception, belongs to the juridical order only in the peculiar form of his ecstasy (Agamben, State of Exception 35). As Derrida pertinently rendered it, the weak messianic "negative theology consists in regarding every [human] predicate ... as inadequate to the essence ... of God"; "only a negative ... attribution can claim to approach God". "God's name would fit everything that cannot be ... designated, except in an indirect and negative way" (Derrida, "How to Avoid" 146). Which particular form does this translation of the untranslatable take in Benjamin's complex understanding of language? 
If we now return to the argument of "The Task of the Translator," Benjamin commits the translator to the above-delineated hidden network of relations, or life. To activate it, s/he must establish a correspondence between the "involuntary memories" of both the original and target languages. ${ }^{5}$ By bringing them into such mutually enriching dialogue, s/he rescues the "language of truth" (80) as their absent origin from its distortion by these two languages (82). Rescuing it means miming its mode of revelation (Offenbarung) in these languages' mode of communication (Mitteilung). Benjamin thus endows the translation with the "special mission" (78) of "a transformation and a renewal" of both languages (77). The more a human tongue mimes the mode of revelation instead of applying the mode of communication, the more space it opens up for its various translations. To Agamben, its successful translation "entails a 'trial' that always involves a plurality of subjects" (State of Exception 39-40). In the formulation of Barbara Cassin, "the untranslatable is what one keeps on (not) translating" (Cassin xiv). In the spirit of weak messianism, the longing of human tongues for the language of truth endlessly postpones its materialization.

Benjamin does not address miming explicitly in "The Task of the Translator," but instead introduces it in two later essays, "The Doctrine of the Similar" and "On the Mimetic Faculty." Therein he opens a genealogy of his "translational" conception of language, stating that the sensuous miming of others, which characterized the pre-modern behavior of humans, gradually gave way to the modern ability to perceive conceptual similitudes. Even if the development from the immediate sensual miming of things to the linguistically mediated non-sensual resemblances implies a historical overcoming, Benjamin nevertheless ultimately interprets language as the "most perfect archive" of seemingly deactivated resemblances. Because it stores, confronts and relates one to another, "the essences of things, their most fleeting and refined substances, even aromas," it is for him "the highest implementation of mimetic faculty" ("Über das mimetische Vermögen" 209). As one of his most astute recent commentators Samuel Weber rightly noticed, Benjamin insists that the language of communication, despite its efforts to part ways with the language of revelation, nevertheless stays "with that from which it parts" (Weber 197). The sensuous miming never

${ }^{5}$ Following Bergson, Freud and Proust, Benjamin introduces a distinction between the voluntary and involuntary memory in his essay "On Some Motifs in Baudelaire" (158). In his understanding, the official belonging of any agency to its present time and space's agencies is systematically subverted by its suppressed longing for those of distant times and spaces. 
stops returning into the conceptual representation, the untranslatable repeatedly breaks into its translation.

In Benjamin's understanding, a linguistic sign is never just an abstract bearer of reference without simultaneously being a material bearer of similitude. Its longing for the language of truth subverts its belonging to a human tongue. ${ }^{6}$ When he describes the sudden manifestation of similitude that swallows up the discrete forms of linguistic signs like a "flame" or a "flash" (Aufblitzen; "Über das mimetische Vermögen" 213), we cannot resist associating his imagery with Freud's image of the flickering-up (Aufleuchten) of involuntary memory traces in human apperceptions. Both "flashes" are bound to "a time-moment [Zeitmoment]" that "slips past" ("The Doctrine" 66). In the alien milieu of communication, these remnants of the language of revelation present themselves "to the eye as fleetingly and transitorily as a constellation of stars" (66). It is the ethical task of the translator to meet their subterraneous longing for redemption by making them join one another in an extraterritorial and extemporal "now-time" (Jetztzeit). Benjamin conceptualizes it as an uncanny fusion of divergent historical epochs, the far-removed fragments of which enter curious "elective affinities" and reverberate with one another ("Über den Begriff” 258).

Repeatedly foregrounding such indistinct composites, Benjamin gradually establishes the untranslatable as the final criterion for its translations. As it announces itself merely "in an indirect and negative way," the more indirect and negative a given manifestation comes to be and the more intense feeling of unhomeliness it induces, the higher the reputation it enjoys in his opinion. In the outcome, Benjamin's concept of the untranslatable amounts to an apology of floating signifiers, i.e. expressions that - in his own plastic rendering - envelop their content "like a royal robe with ample folds" the king's body ("The Task" 79). He estimates their chances for the afterlife as much better than the chances of established and distinct agencies. This holds for not only languages and artworks but creatures as well. For example, in his 1934 essay on Kafka, Benjamin presents the writer's peculiar figure of Odradek as at the same time a most bastardly and most mobile "receptacle of the forgotten" ("Franz Kafka" 132). By his monstrous outlook, Odradek epitomizes the "distorted" "form which things assume in oblivion" (133). However, portrayed as being permanently on the

${ }^{6}$ In fact, while reference has to be attributed to a human tongue's voluntary memory, which makes it belong to a distinct agency, similitude grows from its involuntary memory, which makes it long for the indistinct ones. 
move and with an "indeterminate residence," he "stays alternately in the attic, on the staircase, in the corridors, and in the hall". He is so "extraordinarily mobile and uncatchable" that the "family father" is concerned he will, as his family's most shameful representative, finally outlive it ("Die Sorge" 130).

Among the artworks, Benjamin likewise favors those deprived of aesthetically distinctive identity, in which the "return of the repressed" induced an "expressionless" appearance. "This only completes a work, which destroys it into a bundle of pieces, to the fragment of a true world, to the torso of a symbol," he claims ("Goethes Wablverwandschaften" 181). This uncanny, disaggregate composition of the work of art (das Bruchstückhafte am Kunstwerk; "Zentralpark" 690) as developed in his analyses of various narratives, finds its further elaboration in his conception of allegory from The Origin of German Tragic Drama. In this book, the "torso" of the work of art from the essay on Goethe "Goethes Wahlverwandtschaften" 116) transforms into a "desolate confusion of execution sites" (Der Ursprung 401), by which baroque dramas testify to the misguidances of history. In such a devastated world, the work of art cannot be anything other than a patchwork of remnants, which postpones its completion for an unpredictable future $(355,362)$.

\section{The rule of the state of exception}

We can therefore infer that, when Homi Bhabha, in his post-colonial rendering of today's world, favors indistinct terms of hybridity, liminality, and in-betweenness (Bhabha 12-13), he spontaneously attaches himself to Benjamin's traumatic experience of the post-imperial world, which establishes "the state of exception" as its "rule" ("Über den Begriff" 254). Since then, the state of exception became "the dominant paradigm of government in contemporary politics" (Agamben, State of Exception 2), paving the way for Bhabha's interest in Benjamin. In the aftermath of the First World War, Benjamin sensed that the law exempted itself from the public realm into an impenetrable zone of anomie located beyond human control. His contemporary, Carl Schmitt, defined the state of exception as follows: "[T]he sovereign stands outside of the normally valid juridical order, and yet belongs to it, for it is he who is responsible for deciding whether the constitution can be suspended in toto" (Political Theology 7). In other words, to make the law, his authority does not need to underlie it. We can, therefore, define the post-imperial state of exception as an "included exclusion" of 
its sovereign agency, which makes the operation of the law perilously capricious in the eyes of its subjects.

Benjamin composed his essay on Kafka during the Weimar Republic in French exile. In 1925 Carl Schmitt remarked that "no constitution on earth so easily legalized a coup d'état as did the Weimar Constitution" (Staat, Großraum, Nomos 25), which explains the Republic's regime of a presidential dictatorship and Hitler's subsequent seizure of power. In Kafka's works, as the Republic's banished citizen Benjamin did not fail to notice, the whimsical holders of power uphold its rules only for themselves in order to freely betray and corrupt them (114). Put in these terms, his notion of the untranslatable acquires an eminently political dimension, connoting the uncanny return of the despotic prehistorical law in the democratic world of history. In the shadow of 9/11, Agamben reminded us that "World War One (and the years following it) appear as a laboratory for testing and honing the functional mechanisms and apparatuses of the state of exception" (State of Exception 7). All of a sudden, with the breakup of empires, the distinct identities of many people were reduced to bare life. They were calmly eliminated from the historical "facts" of the world without any established guilt on their part.

In this historical context, it deserves attention that the famous first sentence of Wittgenstein's Tractatus (1921) "The world is all that is the case" - or, more accurately, what the elusive and changeable constellation of its "facts" states is the case - reflects the same uncanny sense of the utter contingency of world affairs. Wittgenstein's two key hypotheses - " $t]$ he sense of the world must lie outside the world" (Tractatus 6.41) and "[i]f there is a worth in the world ... it must lie outside it" (6.53) -refuse to accept the "lie" of the so-called facts as the necessary "order of the world," to put this in the vocabulary of Josef K. from Kafka's Trial (Der Prozeß233). Like Kafka's Josef,7 Wittgenstein instead assumes the existence of an excluded transcendental "order" of which the given worldly "order" is but a distorted manifestation. He reinforces this assumption also through his dictum "Ethics is transcendental" (6.421), which relegates ethics to beyond the boundaries of the politically given world. Through the statement "Ethics and aesthetics are one," parenthesized in the same paragraph, he attributes to art the

${ }^{7}$ On the very eve of his court ordered execution, Josef K. asks himself: "Were there objections that had been forgotten? There must have been some. The logic is irrefutable, but it cannot resist someone who wants to live" (Der Prozeß 241). He therefore equally attaches his hopes to the unexplored potentialities of the world as Wittgenstein, Benjamin, and some other prominent contemporaries do. 
ethical task of saving this transcendental order of oblivion by exploring innumerous possibilities unimplemented by the "factual" world.

Haunted by the feeling of unhomeliness in such a world imposed by history, Benjamin likewise experiences its political distribution of "facts" as discriminating. It dispossesses some of its inhabitants in favor of others, bereaving them of human rights and forcing them into a subhuman existence. These enforced subalterns become the sources of his ethical commitment. They are, as Benjamin formulates in the essay on Kafka, "neither members of, nor strangers to, any ... groups of figures, but, rather, messengers from one to another" (Benjamin, "Franz Kafka" 117). The true redemption comes from their "intermediate worlds" as the containers of that which the historical world has pushed into oblivion. Captured in the swampy ground of fluctuating experiences, the suppressed remnants of the prehistoric time, they break out from the restricted mythic space of an exclusively human history into the wider areas of subhuman creatures beyond the boundaries of the imposed "fate." "Everything forgotten mingles with what has been forgotten of the prehistoric world, forms countless, uncertain, changing compounds, yielding a constant flow of new, strange products" (131). Since the condition of oblivion deforms these in-betweens, writes Benjamin, we feel guilty when we confront them in the attics, broom closets, and corridors in the same way as we used to feel "before the court of justice" (133). Indeed, before the "court of justice" of the postimperial world, these "zones of indistinction" summon us to redeem their inhabitants (134).

In The Origin of German Tragic Drama, Benjamin likens such zones to "the room of a magician, a physicist, a nursery, a junk room, and a pantry," which are cluttered, disordered, and contain all manner of things without any recognizable meaning or context (Der Ursprung 363). However, their seemingly amateurish accumulation of fragments, rubbish, and emblems, "without a strict idea of a goal," in fact expects a "wonder" from the "figural center" that it demarcates (364). From its peculiar "mixture of old elements," it imagines that a "new whole" will emerge (355). Explaining in a letter to Max Brod from November 1917 why his notebooks contain heterogeneous literary fragments without any recognizable ultimate goal, Kafka likewise expresses his "hope that a whole will be made up of these bits, an instance of appeal on whose breasts I will be able to beat when I am in need" (Briefe 195). If it is anywhere in the world, then hope for something new resides in these indistinct mixtures. After all, they are epitomized in Benjamin's own notebooks, which were filled with most diverse quotations. Their main 
task "consisted in tearing fragments out of their context and arranging them afresh in such a way that they illustrated one another and were able to prove their raison d'etre in a free-floating state" (Arendt 47). The U.S.-American anthropologist Elizabeth Povinelli has recently taken up this weak messianic thread by stating that new forms of life persevere as these zones' moments of "miraculization," which never stop disturbing ruling biopolitical formations (Povinelli 10).

\section{The equivocation of in-betweens}

In his essay "How newness enters the world," addressed in the introduction, Bhabha reiterates the delineated Benjamin's messianic engagement of the "zones of indistinction." However, in postcolonial circumstances, he focuses on the new category of in-betweens, detecting them at the boundary between the colony and metropolis. These are colonial migrants and minorities who, in the Western countries as their new domiciles, lead "borderline existences" (Bhabha 218) and live "hybrid hyphenations" (219). Since incommensurable elements make the basis of their cultural identifications - "where difference is neither One nor the Other but something else besides" (219) - they expose the limits of any claim to cultural difference of the metropolis' residents. Their indistinct, neither-nor spaces re-inscribe with their "innovative energy" (220) the forgotten past in the metropolis' present, redrawing its boundaries and opening it toward a different future. By dramatizing through "the indeterminacy of [their] diasporic identity" (225) and their in-between positions "the activity of culture's untranslatability" (224), they ultimately manage to revise the entire "problem of the global space" (223). Within its "body of the law," that is to say, they establish "a series of caesurae and divisions" (Agamben, State of Exception 35), thus turning the global space into the state of exception. Their borderline negotiations hybridize and saturate it with the contingent and indeterminate (Bhabha 225).

In the same way that Benjamin analyzed Kafka's works, Bhabha analyzes Salman Rushdie's Satanic Verses to illustrate such disjunctive rewriting of the global space from the perspective of its in-betweens. According to Benjamin's reading of Kafka, in Jewish tradition, the representative of the official doctrine is the Halakhah, the collective body of Jewish religious laws that has to be duly transmitted through the Haggadah, its narrative implementation. Yet instead of faithfully reproducing the doctrine, Kafka's scattered Haggadah denounces 
its "sickness." In lieu of serving it, his parables "unexpectedly raise a mighty paw against it" (Benjamin, "Some Reflections on Kafka" 143-144). Analogously, as Bhabha spells out, Rushdie subverts the Koran and contests its authority by relocating its truths into the world of minor and migrant "enunciatory positions and possibilities." Like Kafka's, his cultural translation is desacralizing and insurgent (Bhabha 226), stressing the foreign "mode of signification" in the midst of the dominant culture (227). With its "indeterminate temporality of the in-between," the foreign becomes "the unstable element of linkage" to other in-betweens, i.e. of the negation of the dominant culture through negotiation with the dominated ones (227). While establishing themselves through the subject positions that articulate alternative practices and values, minor and migrant agencies forge an "insurgent intersubjectivity" and "affiliative solidarity" (230). Like Benjamin, Bhabha invests his hope in such new commonality that emerges from the linkages between these "unstable elements" across the global space. He accordingly speaks of the "third space" which, negotiating incommensurable differences between the cultures of different epochs and locations "creates a tension peculiar to borderline existences" (218). Its "non-synchronous temporality" that "expands our sensorium to some new dimensions" significantly recalls Benjamin's "now-time" (Jetztzeit) that, with the same effect, establishes affinities between bits and pieces of different times and spaces (Benjamin, "Über den Begriff" 258).

However, by reading the interlocking operations of Indian migrants as a sort of universal emancipation, Bhabha suppresses how they originate in biased phantasms. All subalterns exempt themselves from the frustrating communities which they belong to by forging imagined alliances with spatially and temporally distant others which they long for. Yet, such a self-exemption from the historical law of common belonging into an indeterminate prehistorical law that one is longing for is an equivocal operation. The distant others are by definition inarticulate, which makes them spectrally threatening in the migrants' located perception. Therefore, the migrants first have to 'familiarize' them by attributing them desirable qualities that enable their assimilation into the community-to-come. The consequence of such 'preliminary taming' of the inarticulate others is that a sort of self-assertion inheres to any self-exemption from the rules of the community of belonging. In contrast to Bhabha's perception of the migrants' identifying operation as self-denying, what is actually at stake is an operation of "inverse ventriloquism" (Anderson 198). It is not the unknown others who speak through the migrants' selves but their unknown selves - which they 
hide in front of both the others and themselves - who speak through the others whom they identify with. This means that they dispossess the others of their distinct identities with the covert aim of making up for their own analogous dispossession by the community to which they politically belong. Because distinct identities would oblige the distant others to their particular locations, the migrants blur them to make these others fit their desired liberation.

As the migrants' turning of the distant others into the "floating signifiers" of their desire inadvertently repeats the dispossessing operation that turned them into the migrants, it presents itself as a remedial rather than emancipating undertaking. The proliferation of the hybrid, liminal, and indistinct in-betweens, characteristic of both Benjamin's and Bhabha's idea of worlding, makes up for the loss of distinction that was politically inflicted upon this proliferation's carrier group, i.e., the subjects of hyphenated identities. They were deeply frustrated by the translatio imperii into the nation-states after the dissolution of the German Empire (1918), respectively the British imperial rule in India (1947). Their new countries did not represent the interests of all their peoples equally but rather selectively and unevenly, which means that in both post-imperial Germany and postcolonial India, the former imperial discrimination of 'marginal' and 'inappropriate' population was invigorated instead of being abolished (Brubaker 51-52; Agamben, State of Exception 14-16; Loomba 10-12). Such developments spawned both intellectuals' efforts to search for an alternative, "untranslatable" commonality that would overcome both the imperial and post-imperial, colonial and postcolonial discrimination. In the vocabulary of Gilles Deleuze, both equally victimize a "bastard," "inferior," "missing" people that "ceaselessly stirs beneath dominations," doomed to be "always in becoming, always incomplete" (Deleuze 4). It is in the name of this "always incomplete" people - or "pure potentiality" in the underground of ruling distinctions that it putatively represents $^{8}$-that Benjamin and Bhabha project a community in becoming. In the interpretation of Deleuze and Guattari, " $[\mathrm{t}] \mathrm{o}$ become is not to attain a form ... but to find the zone of proximity, indiscernibility, or indifferentiation where one can no longer be distinguished from a

${ }^{8}$ According to Agamben's famous interpretation ("Bartleby" 243-245), which connects on the previous one proposed by Deleuze (Deleuze 68-90), the exemplary representative of "pure potentiality" is Hermann Melville's figure of Bartleby. Through his notorious hesitation, he engages miming operations to outmaneuver various 'fundamentals' by means of which his political space's appointed guardians eliminate potentiality from it (249). 
woman, an animal, a molecule" (1). Allocating the "bastards," along Benjamin's and Bhabha's lines, ${ }^{9}$ the ethical task of making indistinguishable all that is distinguished, Deleuze and Guattari conceive them as the forces of emancipation and liberation.

However, fifteen years later, Deleuze cautions that the fundamental equivocation of their undertaking might disturb the envisaged emancipation. On the one hand, the "bastards" democratically expropriate dominating agencies, but on the other, in introducing through their devastating "delirium" a worldwide "displacement of races and continents," they simultaneously "erect a race" which is "pure and dominant" (Deleuze 4). "[T]here is always the risk that a diseased state will interrupt the process of becoming ... the constant risk that the delirium of domination will be mixed with a bastard delirium, pushing literature toward a larval fascism, the disease against which it fights" (4). Deleuze's fear concerning the "diseased" state as exemplified in the permanent state of exception echoes the dilemma from the book on Kafka, concerning the final effect of his deterritorializing narrative technique: is it liberating or enslaving, revolutionary or fascist, socialist or capitalist? How to disentangle these two inextricable aspects reliably? The dangers inherent in all-equalizing deterritorializations of identities are exemplified in capitalism, Stalinism, and fascism (Deleuze and Guattari 57) or, as we might now add, various unleashed populisms from more recent time. Once the prehistoric forces of amalgamation break into the historic word of distinctions, it is impossible to prevent the overturning of the envisaged emancipation into mastery, which makes their advocacy a risky enterprise.

To summarize, the questions that have to be raised concerning the deterritorialization of distinct identities amount to the following: Does everyone benefit equally from its all-engulfing whirl, i.e. curi-

${ }^{9}$ Next to the works of Deleuze, Guattari, and Agamben, Benjamin and Bhabha's blurring of distinctions powerfully resonates in the recent work of Emily Apter, who introduced their concept of translation into the vocabulary of comparative literature. Speaking in the name of globalization's victims, she equally privileges literature of exilic consciousness ("Comparative Exile" 92) or one that emerges from a translation failure, mistranslation, the contresense, the unsayable, the inexpressible, and the nonsensical (Against World Literature 9-11). She also only authorizes such a translation of life into its manifestations that fosters and proliferates life's interminable labyrinths. Inasmuch as such translation "belongs fully to no one" but life that negates all property, it is for Apter "a model of deowned literature" (15) or "screwed-up literature" that turns the world of properties upside down (18). Along with Benjamin, Bhabha, Deleuze, and Agamben, she celebrates literature to the degree to which it exempts itself from the world's distinct presence into its remote and indistinct "outside". 
ous tourists and travelling intellectuals parallel to exiles, expatriates and refugees? If the proper human only emerges when it is displaced into the indistinct and inhuman, what about those humans whose obliteration of identity distinctions takes the form of territorial dispossession? What about those who are delivered to an utter deprivation of belonging, confronting the imperative to either leave their proper place or become riveted to the land they have been dispossessed of (Butler, Parting Ways 21-24)? The desire which they have to belong is, by such deterritorializations, forced to acknowledge the impossibility of ever truly belonging (Probyn 8). From this point of view, the longing for a community-to-come is an agent of globalization, which kidnaps the right of belonging to given communities. It creates "at least as much trouble as possibility" and contributes "as much to exploitation and poverty as to wealth creation and economic participation" (Alexander 159). Its inclusiveness rests on exclusion, its tolerance on the long history of imperialism and colonialism accompanied by atrocities (Brown 37-38). Making up for the frustrations that were inflicted on them by their post-imperial, respectively postcolonial, states, Benjamin and Bhabha advocate such a commonality in the permanent state of exception, disregarding its concomitant perilous effects. For it does not deactivate but rather reanimate, strengthen, and expand the ill-reputed sovereignty. It is precisely the suspension of law, which it executes, that makes room for its reemergence in an illegitimate, extra-legal form, characterized by violence.

In the permanent state of exception, the sovereignty acquires the grotesque form of the whimsical, unpredictable, and tyrannical operations of its populist executors. Since their actions are no longer subject to review by any higher judicial authority, their managerial power is invigorated (Butler, Precarious Life 61). In the new form of political legitimacy with no built-in structures of accountability, populist sovereigns usurp the right to suspend rights, which makes their relation to law exploitative, instrumental, and arbitrary. The population is managed through a deconstitution or "spectralization" of its humanity, which increases the disposability and "consumability" of the managed "items" (Bales 25). Ultimately, far from eliminating the compromised sovereignty, the state of exception, through its invention of the translation of the untranslatable, inaugurates a potentially disastrous populist technique for its re-legitimation and rejuvenation. Contrary to what Benjamin and Bhabha envisioned, it acts as the agent of the recuperation of that which it claims to be dethroning. 


\section{WORKS CITED}

Agamben, Giorgio. "Bartleby, Or On Contingency." Potentialities: Collected Essays in Philosophy. Ed. and trans. Daniel Heller-Roazen. Stanford, CA: Stanford University Press, 1999. 243-275.

---. Homo Sacer: Sovereign Power and Bare Life. Trans. Daniel Heller-Roazen. Stanford, CA: Stanford University Press. 1998.

- - - Nudities. Trans. David Kishik and Stefan Pedatella. Stanford, CA: Stanford University Press, 2011.

- - - State of Exception. Trans. Kevin Attell. Chicago: The University of Chicago Press, 2005.

---. The Time that Remains: A Commentary on the Letters to the Romans. Trans. Patricia Dalley. Stanford, CA: Stanford University Press, 2005.

Albrecht, Andrea. Kosmopolitismus: Weltbürgerdiskurse in Literatur, Philosophie und Publizistik um 1800. Berlin and New York: De Gruyter, 2005.

Alexander, Jeffrey. Trauma: A Social Theory. Cambridge and Malden, MA: Polity, 2012.

Anderson, Benedict. Imagined Communities: Reflections on the Origin and Spread of Nationalism. Rev. and ext. edition. London: Verso, 1991.

Apter, Emily. Against World Literature: On the Politics of Untranslatability. London and New York: Verso, 2013.

- - - "Comparative Exile: Competing Margins in the History of Comparative Literature." Comparative Literature in the Age of Multiculturalism. Ed. Charles Bernheimer. Baltimore and London: Johns Hopkins University Press, 1995. 86-97.

Arendt, Hannah. "Walter Benjamin: 1892-1940. Introduction to Walter Benjamin.” Illuminations. Trans. Harry Zohn. New York: Schocken Books, 2007. 1-59.

Bales, Kevin. Disposable People: New Slavery in the Global Economy. Berkeley and Los Angeles and London: University of California Press, 1999.

Beller, Stephen. Vienna and the Jews, 1867-1938: A Cultural History. New York and Cambridge: Cambridge University Press, 1989.

Benjamin, Walter. "Der Ursprung des deutschen Trauerspiels" (1925). Gesammelte Schriften. I-1. Ed. Rolf Tiedemann und Hermann Schweppenhauser. Frankfurt am Main: Suhrkamp, 1980. 203-430.

- - -. "Die Aufgabe des Übersetzers" (1923). Illuminationen: Ausgewählte Schriften. Ed. Siegfried Unseld. Frankfurt am Main: Suhrkamp, 1977. 50-63.

- - . "Doctrine of the Similar" (1933). Trans. Knut Tarkowski. New German Critique 17 (1979). 60-69.

- - -. "Franz Kafka: On the Tenth Anniversary of His Death" (1934). Illuminations. Trans. Harry Zohn. New York: Schocken Books, 2007. 111-141.

- - -. "Goethes Wablverwandtschaften" (1926). Illuminationen: Ausgewählte Schriften. Ed. Siegfried Unseld. Frankfurt am Main: Suhrkamp, 1977. 63-135.

- - . "On Some Motifs in Baudelaire" (1939). Illuminations. Trans. Harry Zohn. New York: Schocken Books, 2007. 155-200.

- - - "Some Reflections on Kafka" (1938). Illuminations. Trans. Harry Zohn. New York: Schocken Books, 2007. 141-145.

-- -. "The Task of the Translator" (1923). Trans. Harry Zohn. The Translation Studies Reader: Second Edition. Ed. Lawrence Venuti. New York and London: Routledge, 2004. 75-83.

- - -. "Über das mimetische Vermögen” (1933). Gesammelte Schriften. II-1. Ed. Rolf 
Tiedemann and Hermann Schweppenhäuser. Frankfurt am Main: Suhrkamp, 1980. 210-213.

- - -. "Zentralpark" (1939). Gesammelte Schriften. I-2. Ed. Rolf Tiedemann und Hermann Schweppenhauser. Frankfurt am Main: Suhrkamp, 1980. 655-690.

- - -. "Zur Kritik der Gewalt" (1921). Gesammelte Schriften. II-1. Ed. RolfTiedemann and Hermann Schweppenhäuser. Frankfurt am Main: Suhrkamp, 1980. 179-204.

Biti, Vladimir. Tracing Global Democracy: Literature, Theory, and the Politics of Trauma. Berlin and Boston: De Gruyter, 2016.

Bhabha, Homi. The Location of Culture. New York and London: Routledge, 1994.

Brown, Wendy. Regulating Aversion: Tolerance in the Age of Identity and Empire. Princeton and New Jersey: Princeton University Press, 2006.

Brubaker, Rogers. Citizenship and Nationhood in France and Germany. Cambridge, MA, and London: Cambridge University Press, 1992.

Butler, Judith. Parting Ways: Jewishness and the Question of Zionism. New York: Columbia University Press, 2012.

- - . Precarious Life: The Powers of Mourning and Violence. London and New York: Verso, 2004.

Cassin, Barbara. "Introduction." Trans. Michael Wood. Dictionary of Untranslatables: A Philosophical Lexicon. Ed. B. Cassin. Trans. and ed. Emily Apter, Jacques Lezra, and Michael Wood. Princeton: Princeton University Press, 2014. xvii-xx.

Deleuze, Gilles. Essays Critical and Clinical. Trans. D. W. Smith and M. A. Greco. London: Verso, 1998.

Deleuze, Gilles, and Guattari, Félix. Kafka: Toward a Minor Literature. Trans. D. Polan. Minneapolis: University of Minnesota Press, 1986.

Derrida, Jacques. "How to Avoid Speaking: Denials." Psyche: Inventions of the Other. Trans. Ken Frieden and Elizabeth Rottenberg. Stanford: Stanford University Press, 2008. 143-196.

Fritzsche, Peter. Stranded in the Present: Modern Time and the Melancholy of History. Cambridge, MA and London: Harvard University Press, 2004.

Herder, Johann Gottfried. Ideen zur Philosophie der Geschichte der Menschheit. Ed. Martin Bollacher. Werke in zehn Bänden. Ed. Martin Bollacher et al. 6. Frankfurt am Main: Deutscher Klassiker Verlag, 1989.

Kafka, Franz. Briefe 1902-1924. Ed. Max Brod. Frankfurt am Main: Fischer, 1966.

- - - . Der Prozeß. In der Fassung der Handschrift. Gesammelte Werke in zwölfBänden. Ed. Hans-Gerd Koch. 3. Frankfurt am Main: Fischer, 1994.

- - -. "Die Sorge des Hausvaters." Erzählungen. Ed. Max Brod. Frankfurt am Main: Fischer, 1986. 129-130.

Koch, Manfred. Weimaraner Weltbewohner: Zur Genese von Goethes Begriff 'Weltliteratur'. Tübingen: Niemeyer, 2002.

Lévi-Strauss, Claude. Introduction to the Work of Marcel Mauss. Trans. F. Baker. London: Routledge, 1987.

Loomba, Ania. Colonialism/Postcolonialism. New York: Routledge, 1998.

Povinelli, Elizabeth A. Economies of Abandonment: Social Belonging and Endurance in Late Liberalism. Durham and London: Duke University Press, 2011.

Schlegel, August Wilhelm. Geschichte der romantischen Literatur: Kritische Schriften und Briefe. Ed. Edgar Lohner. 4. Stuttgart: Kohlhammer, 1965.

Schmitt, Carl. Political Theology. Trans. George Schwab. Cambridge: MIT Press, 1985. - - -. Staat, Großraum, Nomos. Berlin: Duncker \& Humblot, 1995.

Weber, Samuel. Benjamin's-abilities. Boston and Harvard: Harvard University Press, 2010. 
Wiedemann, Conrad. "Deutsche Klassik und nationale Identität: Eine Revision der Sonderwegs-Frage." Klassik im Vergleich. Ed. Wilhelm Voßkamp. Stuttgart: Metzler, 1993. 541-569.

Wittgenstein, Ludwig. Tractatus Logico-Philosophicus. London: Chiron Academic Press, 2016.

\section{Prevajati neprevedliivo: Walter Benjamin in Homi Bhabha}

Ključne besede: prevod / teorija prevajanja / medkulturnost / kulturne razlike / neprevedljivost / postimperializem / postkolonializem / Benjamin, Walter / Bhabha, Homi

Odkar je Homi Bhabha v predzadnjem poglavju svoje knjige Location of Culture uvedel pojem 'kulturnega prevoda', prevod ne implicira več preseganja obstoječih medkulturnih razlik. V njegovi dokaj posebni interpretaciji postane prevajanje proces, ki spodbuja vznik kulturnih razlik na enak način kot denimo življenje nenehno diverzificira svoje stvaritve. Ker te razlike ne pridejo pred prevodom, temveč iz njega izhajajo, so kulture razumljene kot nekaj hibridnega in vmesnega, ne pa kot nekaj čistega in avtonomnega. Prav ta njihova značilnost pa jih po Bhabhovem pojmovanju dela neprevedljive. Kultura se ne more asimilirati v drugo kulturo, ne da bi ohranila svojo notranjo raznolikost, prav kot se ne more osvoboditi od druge kulture, ne da bi utelesila sled te kulture. V končni analizi njegova ideja »o kulturnem prevodu odvzame svetost [...] domnevam o kulturni prevladi«, s tem ko ukinja asimetrijo med jeziki, ki je stoletja spremljala zahodno prevajalsko prakso. Teza, ki jo zagovarjam, je, da pridobi v tem kontekstu njegova uporaba pojma neprevedljivosti, ki jo uvaja že Walter Benjamin v svojem eseju »Prevajalčeva naloga « iz leta 1923, poseben pomen. $\mathrm{Z}$ njo namreč Bhabha vzpostavi skrivno "izbirno sorodnost « med obema mislecema, obsojenima na soočanje s travmatičnimi konstelacijami, v primeru prvega postimperialne, v primeru drugega pa postkolonialne dobe, ki skušata odmisliti politične asimetrije svojih dob.

1.01 Izvirni znanstveni članek / Original scientific article

UDK 81'25:316.7

DOI: https://doi.org/10.3986/pkn.v42.i3.15 